\title{
RELATIVE CONTRIBUTIONS OF PARENT-PERCEIVED CHILD CHARACTERISTICS TO VARIATION IN CHILD FEEDING BEHAVIOR
}

\author{
VICTORIA K. ALDRIDGE \\ Loughborough University and University College London \\ TERENCE M. DOVEY \\ Brunel University \\ CLARISSA I. MARTIN \\ Midlands Psychology, The Hayes, 19 Newport Road, Stafford Staffordshire, ST16 1BA, United Kingdom \\ CAROLINE MEYER \\ Loughborough University and University of Warwick
}

ABSTRACT: Few studies have examined the relative impact of co-occurring child characteristics on problematic feeding behavior. The aim of the current study was to assess the relative contributions of parent-perceived child characteristics in multivariable models of child feeding behavior. One hundred sixty-one mothers reported on their child's feeding behavior and a number of key child characteristics. These characteristics were entered into controlled multivariable models of child feeding behavior, using child and parent frequency domains of the Behavioral Pediatrics Feeding Assessment Scale (BPFAS; W. Crist et al., 1994) as outcome measures. Child feeding problems were positively associated with food neophobia and external behavioral and social issues, but not with most domains of temperamental difficulty or sensory sensitivity. Feeding problem frequency was associated with externalizing symptoms whereas parental perceptions of problems and coping were associated with social-interaction problems in the child. Population feeding problems appear to be external and interactive problems rather than driven by innate or internalizing factors. The association with externalizing symptoms suggests that feeding problems at this level may fall within a wider profile of challenging behavior; however, the existence of problematic feeding behaviors may constitute a challenge for parents only when the child's social interactions also are seen to be deficient.

Keywords: feeding problems, child behavior, temperament, sensory sensitivity, food neophobia

RESUMEN: Trasfondo: Pocos estudios han examinado el impacto relativo de características concurrentes del niño sobre conductas de alimentación problemáticas. El objetivo del presente estudio fue evaluar las contribuciones relativas de las características del niño tal como son percibidas por el progenitor en modelos de variables múltiples de conductas de alimentación del niño.

Métodos: 161 mamás reportaron acerca de la conducta de alimentación de sus niños y un número de características claves del niño. Estas características fueron recogidas dentro de controlados modelos de variables múltiples de conducta de alimentación del niño, usando dominios de frecuencia de progenitores y niños de la Escala de Evaluación de Conducta Pediátrica de Alimentación (BPFAS) como medidas de resultado.

Resultados: Los problemas de alimentación del niño fueron positivamente asociados con la neofobia a la comida y asuntos externos sociales y de conducta, pero no con la mayor parte de los dominios de la dificultad temperamental o la sensibilidad sensorial. La frecuencia de los problemas de alimentación fue asociada con los síntomas de externalización, mientras que las percepciones de los progenitores acerca de los problemas y la forma de arreglárselas fueron asociadas con problemas de interacción social en el niño.

Conclusiones: Los problemas de alimentación en la población parecen ser problemas externos e interactivos, en vez de problemas basados en factores innatos o de internalización. La asociación con síntomas de externalización sugiere que los problemas de alimentación a este nivel pudieran encajar

The research reported in the current article was fully funded by Loughborough University. Ethical approval for the research was granted by the Loughborough University Research Ethics Committee.

Direct correspondence to: Victoria K. Aldridge, Institute of Child Health, University College London, 30 Guilford Street, London, WC1N 1EH, United Kingdom; e-mail: v.aldridge@ucl.ac.uk.

INFANT MENTAL HEALTH JOURNAL, Vol. 37(1), 1-10 (2016)

(C) 2016 The Authors. Infant Mental Health Journal published by Wiley Periodicals, Inc. on behalf of Michigan Association for Infant Mental Health.

DOI: $10.1002 / \mathrm{imhj} .21544$

This is an open access article under the terms of the Creative Commons Attribution-NonCommercial-NoDerivatives License, which permits use and distribution in any medium, provided the original work is properly cited, the use is non-commercial and no modifications or adaptations are made. 
dentro del perfil más amplio de una conducta desafiante. Sin embargo, la existencia de conductas de alimentación problemáticas pudiera constituir solamente un reto para los progenitores cuando las interacciones sociales del niño son también vistas como deficientes.

Palabras claves: problemas de alimentación, temperamento, sensibilidad sensorial, neofobia a la comida

RÉSUMÉ: Contexte: Peu d'étude ont examiné l'impact relatif de caractéristiques simultanées de l'enfant sur le comportement alimentaire problématique. Le but de cette étude était d'évaluer les contributions relatives des caractéristiques perçues par le parent chez des modèles multi-variables de comportement alimentaire.

Méthode: 161 mères ont fait état du comportement alimentaire de leur enfant et d'un nombre de caractéristiques clés de l'enfant. Ces caractéristiques ont été entrées dans des modèles multivariables contrôlés de comportment alimentaire de l'enfant, en utilisant des domaines de fréquence de l'enfant et du parent de l'Echelle d'Evaluation du Comportement Pédiatrique Alimentaire (en anglais Behavioral Pediatrics Feeding Assessment Scale [BPFAS]) en tant que mesures de résultat.

Résultats: Les problèmes alimentaires de l'enfant sont liés de manière positive à la phobie de la nourriture et à des problèmes externes de comportement et sociaux, mais non pas à la plupart des domaines de difficultés de tempérament ou de sensibilité sensorielle. La fréquence des problèmes alimentaires est liée à des symptômes externalisant, alors que les perceptions parentales des problèmes et de la manière de les aborder étaient liées à des problèmes sociaux et à des problèmes d'interaction chez l'enfant.

Conclusions: Les problèmes alimentaires semblent être externes et des problèmes d'interaction, plutôt que des problèmes conduits par des facteurs innés et internalisant. Le lien avec les symptômes externalisants suggère que les problèmes alimentaires à ce niveau pourraient s'avérer du domaine d'un plus grand profil de comportement difficile. Cependant, l'existence de comportements alimentaires problématiques peut également constituer un défi pour les parents lorsque les interactions sociales de l'enfant sont aussi perçues comme étant défectueuses.

Mots clés: problèmes alimentaires, comportement de l'enfant, tempérament, sensibilité sensorielle, phobie de la nourriture

ZUSAMMENFASSUNG: Hintergrund: Nur wenige Studien haben den relativen Einfluss von gleichzeitig vorliegenden kindlichen Eigenschaften auf problematisches Fütterungsverhalten untersucht. Das Ziel der Studie war es, die relativen Beiträge der von den Eltern wahrgenommenen kindlichen Eigenschaften in multivariablen Modellen zum Fütterungsverhalten zu bewerten.

Methoden: 161 Mütter berichteten über das Fütterungsverhalten bei ihren Kindern und über eine Reihe wichtiger Eigenschaften der Kinder. Diese Eigenschaften wurden in kontrollierten multivariablen Modellen zum Fütterungsverhalten bei Kindern eingeschlossen. Für die Erfassung der abhängigen Variable wurden die Häufigkeitsskalen für Kinder und Eltern aus der Behavioral Pediatrics Feeding Assessment Scale (BPFAS) verwendet.

Ergebnisse: Fütterungsprobleme bei Kindern waren positiv mit Lebensmittelneophobie und externalen Verhaltens-und sozialen Aspekten assoziiert, jedoch nicht mit den meisten problematischen Temperamentscharakteristika oder sensorischer Empfindlichkeit. Die Häufigkeit der Fütterungsprobleme wurde mit Externalisierungssymptomen assoziiert, während die elterlichen Problemwahrnehmungen und die Bewältigung mit sozialen Interaktionsproblemen beim Kind assoziiert wurden.

Schlussfolgerungen: Fütterungsprobleme in der Bevölkerung scheinen externe und interaktive Probleme zu sein und sich eher weniger durch angeborene oder internalisierende Faktoren erklären lassen. Die Assoziation mit Externalisierungssymptomen legt nahe, dass Fütterungsprobleme in diesem Ausmaß mit einem größeren Umfang an herausforderndem Verhalten einhergehen. Allerdings stellt das Vorhandensein von problematischen Fütterungsverhalten nur dann eine Herausforderung für die Eltern dar, wenn die soziale Interaktion des Kindes als mangelhaft erachtet wird.

Keywords: Fütterungsprobleme/Fütterstörungen, kindliches Verhalten, Temperament, sensorische Empfindlichkeit, Lebensmittelneophobie

抄録: 背景: 同時に生じる子どもの特徵が、問題のある摂食行動に与える相対的な影響を調査した研究は、ほとんど無かった。この研 究の目的は、親が知覚したperceived子どもの特徵の相対的な寄与を、子どもの摂食行動の多変量モデルで評価することであった。

方法: 161 人の母親が、子どもの摂食行動と主要な子どもの特徵の数を報告した。これらの特徴は、コントロールされた子どもの攝食 行動の多変量モデルに入れられ、行動小児科摂食評価尺度the Behavioral Pediatrics Feeding Assessment Scale (BPFAS)の子どもと親の頻度 の領域を結果測定として用いた。

結果: 子どもの摂食問題は、新しい食べ物への恐怖症、および外的な行動上と社会的な問題とポジティブに関連していたが、気質的な 難しさの大部分の領域、あるいは知覚過敏とは関連していなかった。摂食問題の頻度は、外在化症状と関連したが、その一方問題と対 処についての親の知覚は、子どもの社会-相互交流問題に関連していた。

結論: 集団の摂食問題は、生得的なあるいは内在化問題によって動かされるのではなく、むしろ外在化および相互交流の問題のように みえる。外在化症状との関連から、このレベルの攝食問題が、挑戦的行動の広範なプロフィールのどこかに位置するだろうことが示唆 される。しかし、子どもの社会的相互交流も不十分に見えるとき、問題のある摂食行動の存在は親への挑戦だけを構成するだろう。

キーワード：摂食問題, 子どもの行動, 気質, 知覚過敏, 新しい食べ物への恐怖症

摘要: 背景: 很少研究探討共現的孩子特點對有問題的餵食行為之相對影響。這研究的目的是在兒童餵食行為的多變數模型中, 評估父母感 覺到的孩子特點之相對貢獻。 
方法: 161名母親報告了他們孩子的餵食行為和一些關鍵的兒童特點。這些特點被輸人到一個控制的兒童餵食行為的多變數模型中, 使用行 為兒科餵食定量表 (BPFAS) 中的兒童和父母頻域,作為成果的測量。

結果: 兒童餵食問題分別與食物恐新症和外部行為和社會問題有正面關係, 但與大部份性格困難或感官靈敏度的領域無關。餵食問題的頻率 與外化症狀有關, 而有問題的家長之看法和應對, 與兒童社會交往問題有關。

結論: 人口餵食問題似乎是外部和互動的問題, 而不是被先天或內化因素推動。與外化症狀的關連意味著,在這個級別的餵養問題可能會落 在更廣泛的具有挑戰性行為的範圍裏。然而, 問題的䬶食行為的存在, 可能只在孩子的社會交往也被視為是有缺陷時, 構成對父母的挑戰。

關鍵詞：餵養問題, 兒童行為, 氣質, 感官的靈敏度, 食物恐新症

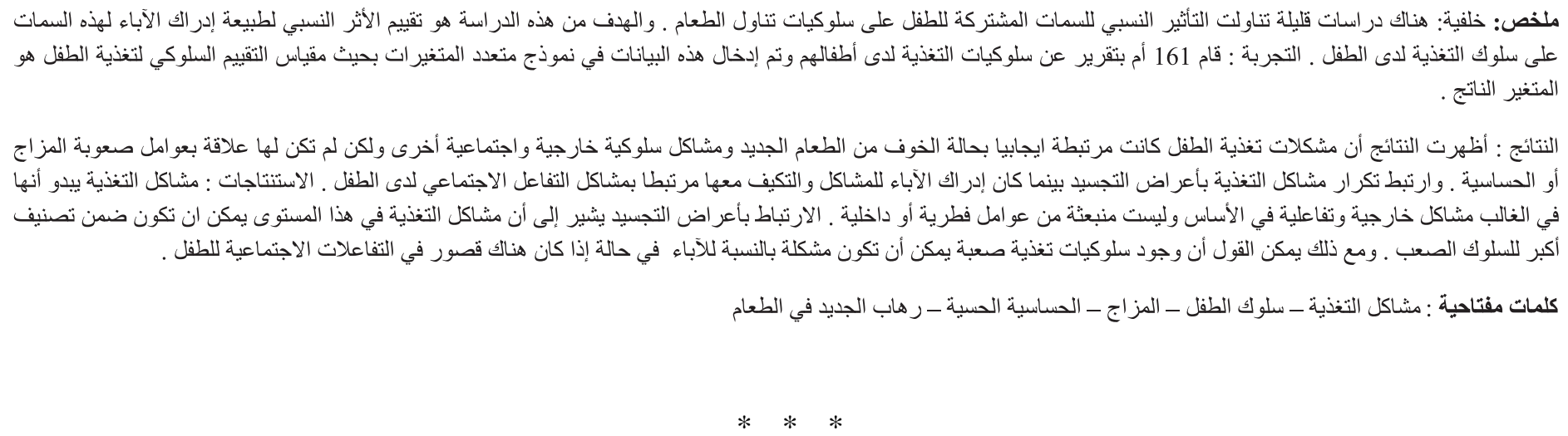

Around half of all parents are estimated to experience difficulties feeding their child at some time, with problems ranging from relatively minor dietary challenges to clinical avoidant/restrictive food intake disorders (Carruth, Ziegler, Gordon, \& Barr, 2004). Because feeding is regarded by many parents as a fundamental parenting responsibility, perceived problems in this area-even at nonclinical levels - can cause considerable concern (Blissett Harris, 2002; Greer, Gulotta, Masler, \& Laud, 2008; Singer, Song, Hill, \& Jaffe, 1990) and have a negative impact on parental self-efficacy, perceptions of parenting, and subsequent parenting behavior (Blissett \& Harris, 2002; Craig, Scambler, \& Spitz, 2003; Crist et al., 1994; Feldman, Keren, Gross-Rozval, \& Tyano, 2004; Fraser, Wallis, \& St John, 2004; Greer et al., 2008; Levine et al., 2011; Lindberg, Bohlin, \& Hagekull, 1994; Powers et al., 2002; Robinson, Drotar, \& Boutry, 2001; Silverman, 2010; Tarkka, 2003). Concerns around feeding and intake have been associated with the use of maladaptive parent feeding strategies such as coercion, coaxing, bribery, and rewards (Birch, 1999; Burklow, McGrath, \& Kaul, 2002; Harris \& Booth, 1992; Linscheid, 2006; Sanders, Patel, Legrice, \& Shepherd, 1993; Wolff \& Herman, 1994; Woods, Borrero, Laud, \& Borrero, 2010) and with deficits in optimal parent problem-solving skills (Martin, Dovey, Coulthard, \& Southall, 2013; Robinson et al., 2001); these factors have be importantly linked to the maintenance and exacerbation of child feeding problems (Piazza et al., 2003). These findings have suggested that parental perceptions of problematic child behaviors and of their own ability to cope with these behaviors can have a significant impact on subsequent parenting approaches and interactions and on future child feeding problems. Therefore, it is important to try to understand population feeding problems, including a profile of key correlates of these problems from the parents' perspective.
An examination of child feeding literature revealed that the most common nonmedical correlates of problematic child feeding behaviors were child temperamental difficulty (Ammaniti, Lucarelli, Cimino, D’Olimpio, \& Chatoor, 2010; Hagekull, Bohlin, \& Rydell, 1997; Niegel, Ystrom, Hagtvet, \& Vollrath, 2008), general child conduct and adjustment problems (Sanders et al., 1993; Wolke, Rizzo, \& Woods, 2002), sensory-processing issues (Coulthard \& Blissett, 2009; Dovey, Isherwood, Aldridge, \& Martin, 2010; Smith, Roux, Naidoo, \& Venter, 2005), and food neophobia (Pliner \& Hobden, 1992). These correlates have typically been examined separately, with various mechanisms for their individual associations with problematic feeding proposed across the literature.

Difficulties in conduct, self-regulation (e.g., hunger, tiredness, emotions), and temperament have been implicated in the development of problematic feeding via the disruptions that they can cause to adaptive parent-child feeding interactions (Ammaniti et al., 2010; Farrow \& Blissett, 2006; Hagekull et al., 1997; Hane, Fox, Polak-Toste, Ghera, \& Guner, 2006). Poor interactions may have a negative impact on the way that parents perceive their child's behaviors and on their own abilities to manage challenging behaviors (Ammaniti et al., 2010). Furthermore, children learn a great deal about what, when, and how to eat via social interactions, so barriers in this area can significantly hinder appropriate feeding behavior and dietary development (Addessi, Galloway, Visalberghi, \& Birch, 2005; Aldridge, Dovey, \& Halford, 2009; Birch, 1999). Externalizing behaviors and temperamental difficulties may also be more directly associated with the frequency of observable feeding problems, if the difficulties impinge on feeding and mealtimes (e.g., poor appetite regulation, restlessness at mealtimes, rigidity around new foods and routines, etc.). Regarding sensory 
processing, food selectivity and refusal behaviors are thought to occur via oversensitivity or overreactivity towards the texture, taste, or smell of certain food groups and types (Berlin, Davies, Lobato, \& Silverman, 2009; Chatoor \& Ganiban, 2003; Coulthard \& Blissett, 2009; Dovey, Farrow, Martin, Isherwood, \& Halford, 2009; Smith et al., 2005), or via underresponsiveness to sensory stimuli and associated poor oral motor control (Berlin et al., 2009). Sensory-processing issues, and the degree of sensitivities, may therefore underlie the frequency or strength of observed feeding problems. Beyond atypical conditions, developmental food neophobia (the reluctance to eat, or avoidance of new foods during early childhood; Pliner \& Hobden, 1992) also has been associated with child feeding problems. Despite being a normal stage of early development (Dovey, Staples, Gibson, \& Halford, 2008), persistence of food neophobia beyond expected time frames is associated with problematic feeding via poor dietary intake (Carruth \& Skinner, 2000; Cooke, 2007; Falciglia, Couch, Gribble, Pabst, \& Frank, 2000; Galloway, Lee, \& Birch, 2003).

The aforementioned characteristics may represent important risk factors for child feeding problems; however, little is known about how they exist together in association with problematic feeding behaviors. It is important to move beyond the simple associations between characteristics and feeding outcomes toward a combined and controlled model of child feeding problems, which, to the best of our knowledge, has not been assessed in any prior study despite the co-occurrence of such factors within individual children and despite widespread knowledge that the role or influence of one factor on an outcome can be attenuated or exacerbated by the presence of another factor (Baron \& Kenny, 1986). Therefore, the primary aim of the current study is to determine the relative contributions of parent-report child characteristics within multivariable models of child feeding behavior. The majority of past research has focused on mothers and maternal report, for practical (highest response rates) and theoretical (Mothers frequently are the primary caregiver.) reasons, and hence, the current study will do the same. Feeding outcomes will be separated into maternally observed problem frequency (child scale) and mothers' perceptions and strategies for coping with feeding problems (parent scale). The aim is to assess whether factors associated with maternal experiences of feeding challenges differ from those associated with maternally observed problem frequency.

Based on existing research, we hypothesize that the child variables associated with feeding problem frequency will differ from those associated with maternal feelings and strategies related to child feeding problems. Specifically, we hypothesize that innate or underlying factors such as sensory sensitivities and temperamental difficulties will be associated with observed feeding problems whereas more external characteristics such as generalized conduct and social interaction problems will be associated with maternal perceptions and strategies for coping with child feeding problems. It is anticipated that child food neophobia will be associated with both feeding outcomes, as it can represent an inherent developmental stage and a behavioral feeding challenge to parents.

\section{METHOD}

\section{Participants and Recruitment}

The overarching study of children's feeding, for which ethical approval was granted by the Loughborough University Research Ethics Committee, obtained data from 445 parents of children with no past or present clinical feeding disorder; the vast majority of the parents were mothers of the child. The current study focuses only on mothers of children aged 3 to 6 years $(N=202)$. Participants were recruited through parent and child social groups and networks. Written information regarding the study purpose, procedure, and contacts was given to all prospective participants by the researcher during visits to parent-child groups or via an online invitation posted on parent forums. Mothers provided informed consent prior to the completion of any study materials. The majority of data $(97 \%)$ were obtained online; recent research has suggested that there are few differences between child feeding questionnaires completed online and offline, and online responses may produce marginally higher feeding problem outcome scores (Dovey, Jordan, Aldridge, \& Martin, 2013).

Individuals with missing feeding behavior outcome data were excluded $(n=41)$, leaving a final sample of 161. After examination of numerous demographic factors, breast-feeding was found to be the only factor to differentiate between those who did and did not complete the outcome measures. Completers had a higher incidence of breast-feeding $(79.2 \%)$ than did noncompleters $(62.5 \%), \chi^{2}=4.90, p=.027$, and completers breast-fed for notably (though not significantly) longer in months $(M=30.80, S D$ $=43.10)$ than did noncompleters $(M=18.18, S D=24.92), t(199)$ $=1.80, p=.074,95 \% \mathrm{CI}=-1.22,26.47$. Breastfeeding was not found to be associated with the study feeding-behavior outcomes, but it was adjusted for in further analyses where required.

Sample mothers. Maternal age ranged from 19 to 46 years $(M=$ $32.68, S D=5.62)$. $75.6 \%$ of the sample were married, $16.9 \%$ cohabiting, and $7.5 \%$ defined themselves as single, separated, or divorced. Finally, $81 \%$ of mothers considered their pregnancy planned and $19 \%$ unplanned.

Subjects. Children were $51.6 \%$ female, with a mean age of 53.80 months $(S D=11.38$, range $=36-83)$. Of the sample, $48.1 \%$ of the children were born on time (37-40 weeks), $45 \%$ were $3+$ days past the due date, and $6.9 \%$ were premature ( $<37$ weeks), with a mean birth weight of $3.44 \mathrm{~kg} \pm 0.57$, range $=1.26-4.63 \mathrm{~kg}$. Most children were breast-fed at some time, with duration ranging from 0 days $(20.8 \%)$ to 212 weeks $(M=30.80, S D=43.10$ weeks $)$. The majority of children had at least one sibling $(76.4 \%$; range $=0-5$ siblings); $67.7 \%$ were the firstborn child, $24.8 \%$ were second-born, and the remaining ranged from third- to fifth-born. Finally, 83.2\% of the sample had no known allergies or intolerances.

\section{Measures and Procedure}

Mothers completed five parent-report psychometric measures assessing child feeding behavior, food neophobia, temperament, 
sensory sensitivities, and general behavior/conduct. The measures were completed in the order presented next. Information also was collected regarding mother and child age, child gender, birth weight, breast-feeding duration, presence of food allergies/intolerances, and number of older and younger siblings.

The Behavioral Pediatrics Feeding Assessment Scale (BPFAS; Crist et al., 1994). The BPFAS assesses child feeding behaviors (25 items) such as "Spits out food" and "Tantrums at mealtimes" as well as parent feelings about, and strategies for dealing with, child feeding behaviors (10 items), such as "I coax my child to get him/her to take a bite." All items are first scored on a Likert scale of 1 (Never) to 5 (Always) and then also scored as "yes" to indicate if the item is considered a problem or "no" to indicate that it is not a problem. Ten items are reverse-scored (e.g., "Eats vegetables"), so that high scores indicate greater problem frequency. The BPFAS yields four domain scores: child behavior frequency (sum of Likert scores; range $=25-125$ ); child behavior problems (count of items rated "yes;" range $=0-25$ ); parent feelings/strategies frequency (range $=10-50)$; and parent feelings/strategies problems (range $=0-10$ ). Due to incomplete reporting for problem domains (i.e., 50-66\% did not fully complete them), only frequency domains (hereafter referred to as child frequency and parent frequency) were used in the current study. The BPFAS has demonstrated good psychometric properties, showing sensitivity to feeding behaviors across clinical and nonclinical child samples, sensitivity to change over time and intervention, and excellent test-retest reliability (Crist et al., 1994; Dovey \& Martin, 2012; Dovey, Martin, Aldridge, Haycraft, \& Meyer, 2011; Haywood \& McCann, 2009). Cronbach's $\alpha$ coefficients of 0.88 (child frequency) and 0.82 (parent frequency) were identified in the current study.

The Child Food Neophobia Scale (CFNS; Pliner, 1994). The CFNS was adapted by Pliner (1994) from the adult Food Neophobia Scale (Pliner \& Hobden, 1992) to assess food neophobia, the tendency to avoid/reject new and unfamiliar foods, in children. The six items of the CFNS are scored on a Likert scale of 1 (Strongly Disagree) to 7 (Strongly Agree), with high scores representing stronger neophobia. The FNS (on which the CFNS is based) has demonstrated strong test-retest reliability $(p<.01)$ and reasonable concurrence with observed food-selection behavior (Hobden Pliner, 1995). In the current study, the CFNS exhibited excellent internal reliability $(\alpha=0.95)$.

The EAS Temperament Questionnaire (Buss \& Plomin, 1984; Mathiesen \& Tambs, 1999). The EAS was developed to examine parental report of child temperament at around 1 to 9 years. Temperament is assessed via 20 items comprising the subscales Emotionality, Activity, Shyness, and Sociability. Items are scored on a Likert scale of 1 (Not at all) to 5 (Very much), with high scores indicating greater difficulty (The Sociability subscale was reversescored.) The EAS subscales have demonstrated good tests-retest and interrater reliability (Boer \& Westenberg, 1994), and internal reliability was confirmed in the current study ( $\alpha$ s range $=0.73-$ $0.87)$.

The Strengths and Difficulties Questionnaire (SDQ; R. Goodman, 1997). The SDQ assesses attributes of psychological adjustment, and was used in the current study to suggest dimensions of child behavior problems. The scale comprises 25 items across five subscales (Emotional Symptoms, Conduct Problems, Hyperactivity-Inattention, Peer Problems, and Pro-Social Behavior), with high scores reflecting increased behavior/adjustment problems (The Prosocial subscale was reverse-scored.) Construct validity, test-retest stability, and adequate subscale internal consistency ( $\alpha$ s range $=0.57-0.85$ ) have been previously identified (R. Goodman, 1997, 2001); the latter was supported in the current study $(\alpha$ range $=0.64-0.76)$.

The Short Sensory Profile (SSP; Dunn, 1994, 1999; Dunn \& Daniels, 2002). The 38-item SSP for children over 3 years was used in the current study. This scale comprises subscales for a number of sensory domains, but only tactile and taste/smell sensitivity were used in the current study. Items are scored on a Likert scale of 1 (Always) to 5 (Never), where low scores indicate sensory processing problems. The SSP measures are used widely in research and clinical practice to examine sensory processing abilities (Ahn, Miller, Milberger, \& McIntosh, 2004; Miller, Coll, \& Schoen, 2007); the current study confirmed internal reliability in the Total scale $(\alpha=0.93)$, the tactile domain $(\alpha=0.71)$, and the taste/smell domain $(\alpha=0.94)$.

\section{Data Analyses}

Up to four missing data items within the BPFAS Outcome scale were imputed to permit calculation of total scores (Crist et al., 1994). For all other measures, scale mean scores (calculated if $\geq 90 \%$ items completed) were used in analyses. Across all covariates, missing data ranged from 0.04 to $25.5 \%$, so a multiple imputation model comprising all child characteristics, feeding outcomes, and demographic variables was used to impute five iterations of missing values (Rubin, 1987). Very few differences were observed in variable scores or model outcomes between pooled imputation results and the original data, suggesting that data were missing at random. To maximize the precision of final estimates, results in the current article are reported from pooled imputation data. Where pooled results are unavailable, the average of values across imputations is given.

Most predictor variables were approximately normally distributed, and mild skew observed in the child and parent frequency scores of the BPFAS did not affect data summaries. Multiple linear regression analyses were used to assess the significance of child variables in combined models of the BPFAS child and parent feeding behavior scores. All collinearity and influence statistics were examined and fell well within acceptable ranges. Residual statistics also were examined for each model and were found to be normally distributed in each case. 
TABLE 1. Child Behavior Characteristics [M, SD, and 95\% Confidence Interval (CI)] of the Total Sample and of Boys and Girls Individually

\begin{tabular}{|c|c|c|c|c|}
\hline \multirow[b]{2}{*}{ Child Variable } & \multicolumn{2}{|c|}{ Total Sample } & \multirow{2}{*}{$\frac{\text { Girls }}{M(S D)}$} & \multirow{2}{*}{$\begin{array}{c}\text { Boys } \\
M(S D)\end{array}$} \\
\hline & $M(S D)$ & $95 \% \mathrm{CI}$ & & \\
\hline BPFAS Child Frequency & $48.87(13.37)$ & $46.79,50.95$ & $47.99(13.11)$ & $49.78(13.67)$ \\
\hline BPFAS Parent Frequency & $17.79(5.96)$ & $16.86,18.72$ & $17.09(5.78)$ & $18.48(6.01)$ \\
\hline CFNS & $3.88(1.73)$ & $3.61,4.15$ & $3.73(1.65)$ & $4.06(1.82)$ \\
\hline Emotionality & $2.72(0.95)$ & $2.56,2.88$ & $2.71(0.85)$ & $2.72(1.06)$ \\
\hline Activity & $4.19(0.63)$ & $4.08,4.29$ & $4.18(0.54)$ & $4.18(0.72)$ \\
\hline Shyness & $2.52(0.83)$ & $2.37,2.66$ & $2.51(0.83)$ & $2.50(0.81)$ \\
\hline Sociability & $3.86(0.64)$ & $3.75,3.97$ & $3.90(0.64)$ & $3.81(0.65)$ \\
\hline Emotional Symptoms & $0.38(0.40)$ & $0.31,0.45$ & $0.40(0.43)$ & $0.36(0.37)$ \\
\hline Conduct Symptoms & $0.45(0.38)$ & $0.38,0.51$ & $0.41(0.34)$ & $0.49(0.42)$ \\
\hline Hyperactivity & $0.81(0.51)$ & $0.72,0.89$ & $0.76(0.49)$ & $0.85(0.53)$ \\
\hline Peer Problems & $0.33(0.36)$ & $0.26,0.39$ & $0.29(0.31)$ & $0.38(0.42)$ \\
\hline Prosocial Behavior & $0.45(0.37)$ & $0.39,0.52$ & $0.36(0.33)$ & $0.55(0.39)^{*}$ \\
\hline Tactile Sensitivity & $4.36(0.59)$ & $4.25,4.47$ & $4.41(0.47)$ & $4.32(0.71)$ \\
\hline Taste/Smell Sensitivity & $4.11(1.15)$ & $3.90,4.32$ & $4.16(1.14)$ & $4.09(1.15)$ \\
\hline
\end{tabular}

Note. BPFAS = Behavioral Pediatrics Feeding Assessment Scale; CFNS = Child Food Neophobia Scale. * Significant difference between girls and boys.

Child feeding literature informed the selection of 12 variables from four main child characteristics (food neophobia, temperament, conduct/adjustment, and sensory sensitivity) for analysis; however, little theory exists regarding the temporal importance of these variables within a multi-element model of feeding outcomes. Therefore, Enter method regression models were used to examine the relative importance of all child characteristics to the child feeding outcomes. All models were adjusted for parent and child demographic factors, and only those found to have no material influence on the model were removed to improve model parsimony.

\section{RESULTS}

\section{Sample Child Behavior Characteristics}

Characteristics of the sample for each of the child behavior outcomes assessed in the current study are presented in Table 1, including summaries for the total sample of completers and for girls and boys independently. All outcome variables were assessed for significant differences between girls and boys, and only prosocial behavior was found to show a significant difference at $5 \%$, $t(115.75)=3.07, p=.003,95 \% \mathrm{CI}:-0.32,-0.069 . P$ values for all other comparisons ranged from 0.15 to 0.99 . To avoid confounding, child gender was adjusted for in subsequent analyses.

\section{Multi-Element Models of Child Feeding Behaviors and Problems}

Child feeding problems (BPFAS Child Frequency subscale). The model of 12 child characteristics explained a substantial and highly significant proportion (adjusted $\mathrm{R}^{2}=0.67$ ) of variability in the BPFAS Child Frequency score, $\mathrm{F}(16,160)=21.27, p<$ .001 . This model was adjusted for mother and child age, child gender, and number of older siblings. Child food neophobia, and behavioral problems associated with conduct and hyperactivity, were significant predictors in the model; data also suggested an inverse relationship between feeding problems and prosocial behavior (see Table 2), although this association was not significant at $5 \%$. Beta coefficients, $95 \%$ confidence intervals, and $p$ values for all covariates are given in Table 2. Although no account is taken for any shared variance that may be observed in the full model, a model containing only the significant predictors and prosocial behavior accounted for a notable $64 \%$ of the variability in the BPFAS Child Frequency scores.

Maternal problems in child feeding (BPFAS Parent Frequency subscale). The model of 12 child characteristics again explained a considerable proportion (adjusted $R^{2}=0.52$ ) of variability in the BPFAS Parent Frequency score, $F(16,160)=10.84, p<.001$. This model was adjusted for mother and child age, child gender, breast-feeding duration, birth weight, and number of younger siblings. In this model, child food neophobia and problems associated with hyperactivity and decreased prosocial behaviors were significant predictors in the model; the confidence interval also suggested a potential inverse relationship between sociability and feeding problems, but this finding was not significant at 5\% (see Table 2). Beta coefficients, confidence intervals, and $p$ values for all covariates are given in Table 2 . A model containing only the significant predictors and sociability was found to explain $50 \%$ of the variability in the BPFAS Parent Frequency scores.

\section{DISCUSSION}

The current study examined the relative associations between several child characteristics and problematic child feeding behavior frequency. It also examined whether there were differences in the profiles of correlates of child feeding problems when assessed via maternally observed behaviors (BPFAS Child Frequency subscale) and maternally reported feelings and strategies for coping with child feeding problems (BPFAS Parent Frequency subscale). 
TABLE 2. Coefficients, 95\% Confidence Intervals (CI), and P Values for Child Characteristics Contributing to Multiple Linear Regression Models of Child Feeding Problems (BPFAS Child and Parent Frequency Outcomes)

\begin{tabular}{|c|c|c|c|c|c|c|}
\hline \multirow[b]{2}{*}{ Child Variable } & \multicolumn{3}{|c|}{ BPFAS Child Frequency ${ }^{a}$} & \multicolumn{3}{|c|}{ BPFAS Parent Frequency ${ }^{b}$} \\
\hline & $\beta$ & $95 \% \mathrm{CI}$ & $p$ & $\beta$ & $95 \% \mathrm{CI}$ & $p$ \\
\hline$\overline{\mathrm{CFNS}}$ & 4.18 & $2.96,5.40$ & $<.001$ & 1.71 & $1.06,2.365$ & $<.001$ \\
\hline Emotionality & 0.023 & $-2.14,2.19$ & .983 & 0.73 & $-0.34,1.80$ & .179 \\
\hline Activity & 0.20 & $-2.48,2.88$ & .885 & 1.15 & $-0.45,2.75$ & .156 \\
\hline Shyness & -1.033 & $-3.20,1.14$ & .347 & -0.73 & $-2.09,0.64$ & .285 \\
\hline Sociability & -1.96 & $-5.59,1.68$ & .288 & -2.13 & $-4.34,0.07$ & .058 \\
\hline Emotional Symptoms & 0.98 & $-5.34,7.31$ & .749 & 0.58 & $-1.88,3.04$ & 643 \\
\hline Conduct Symptoms & 5.56 & $0.36,10.76$ & .036 & 0.56 & $-1.93,3.05$ & .658 \\
\hline Hyperactivity & 6.64 & $3.28,10.00$ & $<.001$ & 2.95 & $0.26,5.63$ & .034 \\
\hline Peer Problems & 1.80 & $-3.42,7.01$ & .497 & 0.09 & $-2.88,3.06$ & .951 \\
\hline Prosocial Behavior & -3.72 & $-7.65,0.20$ & .063 & -2.62 & $-4.98,-0.25$ & .031 \\
\hline Tactile Sensitivity & -0.24 & $-3.24,2.77$ & .877 & 0.82 & $-.86,2.51$ & .333 \\
\hline Taste/Smell Sensitivity & -1.62 & $-3.51,0.26$ & .090 & -0.41 & $-1.40,0.57$ & .408 \\
\hline Adjusted $\mathrm{R}^{2}$ & 0.67 & 0.52 & & & & \\
\hline
\end{tabular}

\section{Note.}

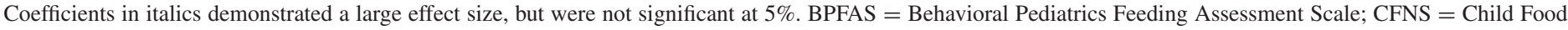
Neophobia Scale.

${ }^{a}$ Model adjusted for mother and child age, child gender, and number of older siblings.

${ }^{b}$ Model adjusted for mother and child age, child gender, breast-feeding duration, birth weight, and number of younger siblings.

Notably, the current study found that models comprising only a small number of significant child characteristics could explain over half of all variability in the BPFAS Parent Frequency scores and a remarkable two thirds of the variability in BPFAS Child Frequency scores. These models were controlled for a number of demographic variables, but follow-up analyses suggested that the vast majority of the variance accounted for in each model could be attributed to the significant predictors. While the cross-sectional nature of the current study precludes inferences around cause and effect between child characteristics and feeding, the strength of the results suggests that the models uncovered in this study represent key profiles of characteristics to focus on in the reduction or prevention of population-level child feeding problems. Given that the characteristics were maternally reported, such methods of reduction/prevention would likely need to focus on both the child's behaviors and the parent's perceptions of those behaviors. Our hypotheses that the models of child and parent outcomes would differ and that different child characteristics would prevail for each outcome were partially supported by the data. The specific pattern of predictors and the total model explanatory values differed slightly between the models of child and parent feeding outcomes, and certain characteristics were found to play a greater role in the BPFAS Child Frequency scores while others were more highly associated with the BPFAS Parent Frequency scores.

The current study found that child food neophobia and behavioral hyperactivity were strongly and positively associated with both child and parent frequency domains of problematic child feeding behavior. Accounting for the relative scales of measurement, the strength of these predictors was similar and noteworthy for each outcome scale. A single unit increase in food neophobia was associated with a $16.7 \%$ (minimum $11.8 \%$ ) increase in the
BPFAS Child Frequency scores and a 17.1\% (minimum 10.6\%) increase in the BPFAS Parent Frequency scores. Similarly, a unit increase in hyperactivity was associated with a $26.6 \%$ (minimum $13.1 \%$ ) increase in child scores and a more variable $29.5 \%$ (minimum $2.6 \%$ ) increase in parent scores. The frequency of observed problematic feeding behaviors (BPFAS Child Frequency subscale) also was positively associated with behavioral conduct problems, which, coupled with hyperactivity, reflect a profile of externalizing behaviors (A. Goodman, Lamping, \& Ploubidis, 2010; Liu, 2004). Rather than conduct problems, the parental problem scale (BPFAS Parent Frequency subscale) was significantly negatively associated with prosocial child behavior, and distinctly, but nonsignificantly, negatively associated with sociability. Prosocial deficits were marked, but not significant, in relation to the frequency of observed child feeding problems. Aside from social domains, no other facets of temperamental difficulty were associated with problematic feeding behavior frequency. The absence of emotional symptoms (either behavioral or temperamental) alongside social deficits in models of problematic feeding behavior suggests that it is socialinteraction deficits specifically that correlate with feeding issues rather than signifying broader internalizing-behavior profiles. The additional absence of sensory sensitivities from the predictive models also suggests that psychophysiological factors do not routinely underpin population feeding problems.

These key findings suggest that population-level child feeding problems are predominantly active and interactive issues for the mother and child, co-occurring or perhaps falling within other externalizing-type behavior profiles rather than underlying emotional, temperamental, or physiological issues. The findings also suggest that mothers may observe a range of problems with their child's feeding and general interaction with their environment (Liu, 
2004), but the perceived presence of child social problems may be the distinguishing marker for the perception of problematic feeding behaviors as a challenge to parenting. This ties in with a body of research which advocates the importance of socialization throughout feeding/eating development as a means for teaching and learning about what, where, when, and how to eat (e.g., Addessi et al., 2005; Birch, 1998, 1999; Nestle et al., 1998). Difficulties in this area therefore can hinder natural learning techniques and impact on the parent's ability to manage or overcome feeding problems. It was identified earlier in the article that parental/maternal perception of feeding problems can have a significant negative impact on the parent's subsequent actions, feeding strategies, and parental self-efficacy. As such, the current results suggest that deficits to social interactions may represent a key risk factor to this negative association and potential downward spiral of feeding behavior. Advice, support, and interventions for poor feeding, based around improvement of socialization and interaction, therefore may be beneficial to the mother and child in the general population, although more research would be needed to test this supposition. The absence of sensory and temperament or regulatory factors in the models of child feeding also may have important implications for the differentiation of clinical and nonclinical feeding problems; again, further research would be required to test this assertion.

It is recognized that all outcome variables in this current study were maternally reported, and as such, reflect the mother's perceptions of her child's behaviors and actions. While parentalreports can represent over- or underreporting biases, as compared to objective measures of the child, all chosen measures in this study have been positively validated against objectively observed behaviors and characteristics, which helps ensure that bias has been minimized. Notably, parental perceptions of child behavior are of practical importance to the current study since it is these perceptions of a child's behaviors, and a parent's ability to manage those behaviors, which can influence the parent's own behaviors and strategies. The study also observed that mothers who did not complete the feeding-outcome measures had a lower incidence of breast-feeding. In the current study, breast-feeding duration was not found to be associated with feeding-behavior outcomes, and importantly, a notable proportion of the mothers who did complete the feeding measures did not breast-feed. These factors help to suggest that the results of the study were not confounded by breastfeeding status or duration. However, the difference between groups does suggest that mothers who did not breast-feed their child were more reluctant to report on their child's feeding, which could be a very interesting factor to investigate in future research.

A limitation to the current study was that ethnicity and socioeconomic data were incomplete and thus not reported. However, estimates available from the overarching child feeding study have suggested that a predominantly White British sample was obtained, but a reasonably broad spectrum of socioeconomic backgrounds was represented via paid, voluntary, or full-time parenting roles, although very few mothers were identified as unemployed. In future research, more detailed information should be collected on these factors to control for their potential influence on child feeding outcomes.

The strength and nature of the current study findings are noteworthy. The study gives a clear profile of child characteristics that explain a huge amount of the variability in poorer feeding behaviors in the population. Two thirds of the variability in problematic feeding behavior frequency was explained by a multivariable regression model in which only child hyperactivity, conduct symptoms, and food neophobia were significant predictors. Maternal perceptions of child feeding problems as challenging were not associated with child conduct problems, but instead were significantly associated with child social deficits. This key correlate amplifies the importance of social interaction within feeding development and behavior, and may indicate a crucial focus for parental support in overcoming feeding problems.

\section{REFERENCES}

Addessi, E., Galloway, A.T., Visalberghi, E., \& Birch, L.L. (2005). Specific social influences on the acceptance of novel foods in 2-5-year-old children. Appetite, 45(3), 264-271. doi:10.1016/j.appet.2005.07.007

Ahn, R.R., Miller, L.J., Milberger, S., \& McIntosh, D.N. (2004). Prevalence of parents' perceptions of sensory processing disorders among kindergarten children. American Journal of Occupational Therapy, 58(3), 287-293.

Aldridge, V., Dovey, T.M., \& Halford, J.C.G. (2009). The role of familiarity in dietary development. Developmental Review, 29(1), 32-44. doi:10.1016/J.Dr.2008.11.001

Ammaniti, M., Lucarelli, L., Cimino, S., D’Olimpio, F., \& Chatoor, I. (2010). Maternal psychopathology and child risk factors in infantile anorexia. International Journal of Eating Disorders, 43(3), 233-240. doi:10.1002/Eat.20688

Baron, R.M., \& Kenny, D.A. (1986). The moderator mediator variable distinction in social psychological research-Conceptual, strategic, and statistical considerations. Journal of Personality and Social Psychology, 51(6), 1173-1182. doi:10.1037/0022-3514.51.6.1173

Berlin, K.S., Davies, W.H., Lobato, D.J., \& Silverman, A.H. (2009). A biopsychosocial model of normative and problematic pediatric feeding. Children's Health Care, 38(4), 263-282. doi:10.1080/02739610903235984

Birch, L.L. (1998). Development of food acceptance patterns in the first years of life. Proceedings of the Nutrition Society, 57(4), 617-624. doi:10.1079/Pns19980090

Birch, L.L. (1999). Development of food preferences. Annual Review of Nutrition, 19, 41-62. doi:10.1146/annurev.nutr.19.1.41

Blissett, J., \& Harris, G. (2002). A behavioural intervention in a child with feeding problems. Journal of Human Nutrition and Dietetics, 15(4), 255-260.

Boer, F., \& Westenberg, P.M. (1994). The factor structure of the Buss and Plomin EAS Temperament Survey (Parental Ratings) in a Dutch sample of elementary school children. Journal of Personality Assessment, 62(3), 537-551. doi:10.1207/s15327752jpa6203_13 
Burklow, K.A., McGrath, A.M., \& Kaul, A. (2002). Management and prevention of feeding problems in young children with prematurity and very low birth weight. Infants \& Young Children, 14(4), 19-30.

Buss, A.H.P., \& Plomin, R. (1984). Temperament: Early developing personality traits. Hillsdale, NJ: Erlbaum.

Carruth, B.R., \& Skinner, J.D. (2000). Revisiting the picky eater phenomenon: Neophobic behaviors of young children. Journal of the American College of Nutrition, 19(6), 771-780.

Carruth, B.R., Ziegler, P.J., Gordon, A., \& Barr, S.I. (2004). Prevalence of picky eaters among infants and toddlers and their caregivers' decisions about offering a new food. Journal of the American Dietetic Association, 104(1), S57-S64. doi:10.1016/j.jada.2003.10.024

Chatoor, I., \& Ganiban, J. (2003). Food refusal by infants and young children: Diagnosis and treatment. Cognitive and Behavioral Practice, 10(2), 138-146. doi:10.1016/S1077-7229(03)80022-6

Cooke, L. (2007). The importance of exposure for healthy eating in childhood: A review. Journal of Human Nutrition and Dietetics, 20(4), 294-301. doi:10.1111/j.1365-277X.2007.00804.x

Coulthard, H., \& Blissett, J. (2009). Fruit and vegetable consumption in children and their mothers. Moderating effects of child sensory sensitivity. Appetite, 52(2), 410-415. doi:10.1016/j.appet.2008.11.015

Craig, G.M., Scambler, G., \& Spitz, L. (2003). Why parents of children with neurodevelopmental disabilities requiring gastrostomy feeding need more support. Developmental Medicine and Child Neurology, 45(3), 183-188. doi:10.1017/S0012162203000355

Crist, W., Mcdonnell, P., Beck, M., Gillespie, C.T., Barrett, P., \& Mathews, J. (1994). Behavior at mealtimes and the young child with cystic fibrosis. Journal of Developmental and Behavioral Pediatrics, 15(3), $157-161$.

Dovey, T.M., Farrow, C.V., Martin, C.I., Isherwood, E., \& Halford, J.C.G. (2009). When does food refusal require professional intervention? Current Nutrition and Food Science, 5(3), 160-171.

Dovey, T.M., Isherwood, E., Aldridge, V.K., \& Martin, C. (2010). Typology of feeding disorders based on a single assessment system: Formulation of a clinical decision-making model. Infant, Child, \& Adolescent Nutrition, 2(1), 45-51.

Dovey, T.M., Jordan, C., Aldridge, V.K., \& Martin, C.I. (2013). Screening for feeding disorders. Creating critical values using the behavioural pediatrics feeding assessment scale. Appetite, 69, 108-113. doi:10.1016/j.appet.2013.05.019

Dovey, T.M., \& Martin, C.I. (2012). A quantitative psychometric evaluation of an intervention for poor dietary variety in children with a feeding problem of clinical significance. Infant Mental Health Journal, 33(2), 148-162. doi:10.1002/imhj.21315

Dovey, T.M., Martin, C.I., Aldridge, V.K., Haycraft, E., \& Meyer, C. (2011). Measures, measures everywhere, but which ones should I use? The Feeding News, 6(1), 1-13.

Dovey, T.M., Staples, P.A., Gibson, E.L., \& Halford, J.C. (2008). Food neophobia and 'picky/fussy' eating in children: A review. Appetite, 50(2-3), 181-193. doi:10.1016/j.appet.2007.09.009

Dunn, W. (1994). Performance of typical children on the Sensory ProfileAn item analysis. American Journal of Occupational Therapy, 48(11), 967-974.
Dunn, W. (1999). Development and validation of the short sensory profile. In W. Dunn (Ed.), The sensory profile examiner's manual (pp. 59-73) . San Antonio, TX: Psychological Corporation.

Dunn, W., \& Daniels, D.B. (2002). Initial development of the Infant/Toddler Sensory Profile. Journal of Early Intervention, 25(1), 27-41. doi:10.1177/105381510202500104

Falciglia, G.A., Couch, S.C., Gribble, L.S., Pabst, S.M., \& Frank, R. (2000). Food neophobia in childhood affects dietary variety. Journal of the American Dietetic Association, 100(12), 1474-1281. doi:10.1016/S0002-8223(00)00412-0

Farrow, C., \& Blissett, J. (2006). Maternal cognitions, psychopathologic symptoms, and infant temperament as predictors of early infant feeding problems: A longitudinal study. International Journal of Eating Disorders, 39(2), 128-134. doi:10.1002/Eat.20220

Feldman, R., Keren, M., Gross-Rozval, O., \& Tyano, S. (2004). Motherchild touch patterns in infant feeding disorders: Relation to maternal, child, and environmental factors. Journal of the American Academy of Child \& Adolescent Psychiatry, 43(9), 1089-1097. doi:10.1097/01.chi.0000132810.98922.83

Fraser, K., Wallis, M., \& St John, W. (2004). Improving children's problem eating and mealtime behaviours: An evaluative study of a single session parent education programme. Health Education Journal, 63(3), 229-241.

Galloway, A.T., Lee, Y., \& Birch, L.L. (2003). Predictors and consequences of food neophobia and pickiness in young girls. Journal of the American Dietetic Association, 103(6), 692-698. doi:10.1053/jada.2003.50134

Goodman, A., Lamping, D.L., \& Ploubidis, G.B. (2010). When to use broader internalising and externalising subscales instead of the hypothesised five subscales on the Strengths and Difficulties Questionnaire (SDQ): Data from British parents, teachers and children. Journal of Abnormal Child Psychology, 38(8), 1179-1191. doi:10.1007/s10802-010-9434-x

Goodman, R. (1997). The Strengths and Difficulties Questionnaire: A research note. Jul 1997. Child Psychology and Psychiatry and Allied Disciplines, 38(5), 581-586. doi:10.1111/j.14697610.1997.tb01545.x 9255702

Goodman, R. (2001). Psychometric properties of the Strengths and Difficulties Questionnaire. Journal of the American Academy of Child \& Adolescent Psychiatry, 40(11), 1337-1345. doi:10.1097/00004583200111000-00015

Greer, A.J., Gulotta, C.S., Masler, E.A., \& Laud, R.B. (2008). Caregiver stress and outcomes of children with pediatric feeding disorders treated in an intensive interdisciplinary program. Journal of Pediatric Psychology, 33(6), 612-620. doi:10.1093/jpepsy/ jsm116

Hagekull, B., Bohlin, G., \& Rydell, A.M. (1997). Maternal sensitivity, infant temperament, and the development of early feeding problems. Infant Mental Health Journal, 18(1), 92-106. doi:10.1002/(SICI)10970355(199721)18:1<92::AID-IMHJ7>3.0.Co;2-2

Hane, A.A., Fox, N.A., Polak-Toste, C., Ghera, M.M., \& Guner, B.M. (2006). Contextual basis of maternal perceptions of infant temperament. Developmental Psychology, 42(6), 1077-1088. doi:10.1037/0012-1649.42.6.1077 
Harris, G.B., \& Booth, I.W. (1992). The nature and management of eating problems in pre-school children. In Feeding problems and eating disorders in children and adolescents (pp. 61-84).

Haywood, P., \& McCann, J. (2009). A brief group intervention for young children with feeding problems. Clinical Child Psychology and Psychiatry, 14(3), 361-372. doi:10.1177/1359104509104046

Hobden, K., \& Pliner, P. (1995). Effects of a model on food neophobia in humans. Appetite, 25(2), 101-113. doi:10.1006/appe.1995. 0046

Levine, A., Bachar, L., Tsangen, Z., Mizrachi, A., Levy, A., Dalal, I. et al. (2011). Screening criteria for diagnosis of infantile feeding disorders as a cause of poor feeding or food refusal. Journal of Pediatric Gastroenterology and Nutrition, 52(5), 563-568. doi:10.1097/MPG.0b013e3181ff72d2

Lindberg, L.B., Bohlin, G., \& Hagekull, B. (1994). Infant food refusal and parental social support. Early Development and Parenting, 3(3), $153-159$.

Linscheid, T.R. (2006). Behavioral treatments for pediatric feeding disorders. Behavior Modification, 30(1), 6-23. doi: $10.1177 / 0145445505282165$

Liu, J. (2004). Childhood externalizing behavior: Theory and implications. Journal of Child and Adolescent Psychiatric Nursing, 17(3), 93-103. doi:10.1111/j.1744-6171.2004.tb00003.x15535385

Martin, C.I., Dovey, T.M., Coulthard, H., \& Southall, A.M. (2013). Maternal stress and problem-solving skills in a sample of children with nonorganic feeding disorders. Infant Mental Health Journal, 34(3), 202-210. doi:10.1002/imhj.21378

Mathiesen, K.S., \& Tambs, K. (1999). The EAS Temperament Questionnaire-Factor structure, age trends, reliability, and stability in a Norwegian sample. Journal of Child Psychology and Psychiatry, 40(03), 431-439.

Miller, L.J., Coll, J.R., \& Schoen, S.A. (2007). A randomized controlled pilot study of the effectiveness of occupational therapy for children with sensory modulation disorder. American Journal of Occupational Therapy, 61(2), 228-238.

Nestle, M., Wing, R., Birch, L., DiSogra, L., Drewnowski, A., Middleton, S. et al. (1998). Behavioral and social influences on food choice. Nutrition Reviews, 56(5), S50-S64.

Niegel, S., Ystrom, E., Hagtvet, K.A., \& Vollrath, M.E. (2008). Difficult temperament, breastfeeding, and their mutual prospective effects: The Norwegian Mother and Child Cohort Study. Journal of Developmental and Behavioral Pediatrics, 29(6), 458-462. doi:10.1097/Dbp.0b013e3181877a88
Piazza, C.C., Fisher, W.W., Brown, K.A., Shore, B.A., Patel, M.R., Katz, R.M. et al. (2003). Functional analysis of inappropriate mealtime behaviors. Journal of Applied Behavior Analysis, 36(2), 187-204. doi:10.1901/jaba.2003.36-187

Pliner, P. (1994). Development of measures of food neophobia in children. Appetite, 23(2), 147-163. doi:10.1006/appe.1994.1043

Pliner, P., \& Hobden, K. (1992). Development of a scale to measure the trait of food neophobia in humans. Appetite, 19(2), 105-120. doi:10.1016/0195-6663(92)90014-W

Powers, S.W., Byars, K.C., Mitchell, M.J., Patton, S.R., Standiford, D.A., \& Dolan, L.M. (2002). Parent report of mealtime behavior and parenting stress in young children with type 1 diabetes and in healthy control subjects. Diabetes Care, 25(2), 313-318. doi:10.2337/diacare.25.2.313

Robinson, J.R., Drotar, D., \& Boutry, M. (2001). Problem-solving abilities among mothers of infants with failure to thrive. Journal of Pediatric Psychology, 26(1), 21-32.

Rubin, D.B. (1987). Multiple imputation for nonresponse in surveys. New York: Wiley.

Sanders, M.R., Patel, R.K., Legrice, B., \& Shepherd, R.W. (1993). Children with persistent feeding difficulties-An observational analysis of the feeding interactions of problem and nonproblem eaters. Health Psychology, 12(1), 64-73. doi:10.1037/0278-6133.12.1.64

Silverman, A.H. (2010). Interdisciplinary care for feeding problems in children. Nutrition in Clinical Practice, 25(2), 160-165. doi:10.1177/0884533610361609

Singer, L.T., Song, L.Y., Hill, B.P., \& Jaffe, A.C. (1990). Stress and depression in mothers of failure-to-thrive children. Journal of Pediatric Psychology, 15(6), 711-720.

Smith, A.A., Roux, S., Naidoo, N.T., \& Venter, D.J.L. (2005). Food choices of tactile defensive children. Nutrition, 21(1), 14-19. doi:10.1016/j.nut.2004.09.004

Tarkka, M.T. (2003). Predictors of maternal competence by first-time mothers when the child is 8 months old. Journal of Advanced Nursing, 41(3), 233-240.

Wolff, R.P.H., \& Herman, C.J. (1994). Management of behavioral feeding problems in young children. Infants \& Young Children, 7(1), 14-23.

Wolke, D., Rizzo, P., \& Woods, S. (2002). Persistent infant crying and hyperactivity problems in middle childhood. Pediatrics, 109(6), 10541060. doi:10.1542/peds.109.6.1054

Woods, J.N., Borrero, J.C., Laud, R.B., \& Borrero, C.S. (2010). Descriptive analyses of pediatric food refusal: The structure of parental attention. Behavior Modification, 34(1), 35-56. doi:10.1177/0145445509355646 